\title{
Chemical Characteristics of Precipitation in a Typical Urban Site of the Hinterland in Three Gorges Reservoir, China
}

\author{
Liuyi Zhang $\mathbb{D}^{1,2,3}$ Baoqing Qiao, ${ }^{1,2}$ Huanbo Wang, ${ }^{1}$ Mi Tian, ${ }^{1}$ \\ Jian Cui $\oplus^{1},{ }^{1,3}$ Chuan Fu, ${ }^{3}$ Yimin Huang, ${ }^{3}$ and Fumo Yang $\mathbb{C}^{1,2,3,4}$ \\ ${ }^{1}$ CAS Key Laboratory of Reservoir Environment, Chongqing Institute of Green and Intelligent Technology, Chinese Academy of Sciences, \\ Chongqing 400714, China \\ ${ }^{2}$ University of Chinese Academy of Sciences, Beijing 100049, China \\ ${ }^{3}$ Key Laboratory of Water Environment Evolution and Pollution Control in Three Gorges Reservoir, Chongqing Three Gorges University, \\ Wanzhou 404100, China \\ ${ }^{4}$ CAS Center for Excellence in Regional Atmospheric Environment, Institute of Urban Environment, Chinese Academy of Sciences, \\ Xiamen 361021, China
}

Correspondence should be addressed to Fumo Yang; fmyang@cigit.ac.cn

Received 26 October 2017; Revised 5 January 2018; Accepted 18 February 2018; Published 19 March 2018

Academic Editor: Franco Tassi

Copyright (C) 2018 Liuyi Zhang et al. This is an open access article distributed under the Creative Commons Attribution License, which permits unrestricted use, distribution, and reproduction in any medium, provided the original work is properly cited.

\begin{abstract}
Major water-soluble ions were analyzed for two-year precipitation samples in Wanzhou, a typical urban site of the hinterland of Chinese Three Gorges Reservoir. The $\mathrm{pH}$ values of the precipitation were in the range of 4.0 to 8.3, and the volume-weighted mean $($ VWM $)$ value was 5.0. The concentration order of anions and cations was as follows: $\mathrm{SO}_{4}{ }^{2-}>\mathrm{NO}_{3}{ }^{-}>\mathrm{Cl}^{-}>\mathrm{F}^{-}$and $\mathrm{NH}_{4}^{+}>\mathrm{Ca}^{2+}>$ $\mathrm{Na}^{+}>\mathrm{K}^{+}>\mathrm{Mg}^{2+}$, respectively. Good correlations were found between $\mathrm{SO}_{4}{ }^{2-}$ and $\mathrm{NH}_{4}{ }^{+}, \mathrm{SO}_{4}{ }^{2-}$ and $\mathrm{Ca}^{2+}, \mathrm{NO}_{3}{ }^{-}$and $\mathrm{NH}_{4}{ }^{+}$, and $\mathrm{NO}_{3}{ }^{-}$and $\mathrm{Ca}^{2+}$, implying their co-occurrence in the precipitation, most likely as $\left(\mathrm{NH}_{4}\right)_{2} \mathrm{SO}_{4},\left(\mathrm{NH}_{4}\right) \mathrm{HSO}_{4}, \mathrm{NH}_{4} \mathrm{NO}_{3}, \mathrm{CaSO}_{4}$, and $\mathrm{Ca}\left(\mathrm{NO}_{3}\right)_{2}$. The sum of all measured ions was $416.4 \mu \mathrm{eq} \mathrm{L}-1$, indicating serious air pollution in Wanzhou. $\mathrm{NH}_{4}^{+}$and $\mathrm{Ca}^{2+}$ were the most important ions neutralizing the acidic compounds in the precipitation; their major sources included agricultural activity and crustal dust. Local anthropogenic activities, for example, coal burning and traffic related sources, contributed most of $\mathrm{SO}_{4}{ }^{2-}$ and $\mathrm{NO}_{3}{ }^{-}$. The equivalent concentration ratio of $\mathrm{SO}_{4}{ }^{2-} / \mathrm{NO}_{3}{ }^{-}$was 4.5 , indicating that excessive emission of sulfur was the main reason leading to the precipitation acidity in Wanzhou. However, this ratio was lower than the ratio (5.9) in 2000s in Wanzhou, indicating that the contribution of nitric acid to the acidity of precipitation was strengthening.
\end{abstract}

\section{Introduction}

Precipitation is an important means of scavenging airborne pollutants, including in-cloud scavenging (rainout) and below-cloud scavenging (washout) [1]. With the accelerated urbanization and industrialization, excessive pollutants have emitted into the atmosphere in China, for example, nitrogen oxides $\left(\mathrm{NO}_{x}\right)$, sulfur dioxide $\left(\mathrm{SO}_{2}\right)$, and particulate matter (PM). These pollutants can dissolve in precipitation and then return to surface through wet deposition. Precipitation that contains a large amount of pollutants would cause a series of negative ecological effects on the surface ecosystem, for example, soil acidification, eutrophication, and biodiversity reduction.

It has been observed that precipitation was contaminated worldwide because of the excessive emission of atmospheric pollutants. These pollutants can change the chemical characteristics of precipitation during the scavenging process depending on the solubility [2]. Chemical compositions of precipitation were influenced by the type of pollutant, meteorology, and topographic structure. Therefore, different regions have very different chemical composition in precipitation. Generally, $\mathrm{Na}^{+}$and $\mathrm{Cl}^{-}$are abundant along coastal areas [3]; $\mathrm{Ca}^{2+}$ and $\mathrm{Mg}^{2+}$ are abundant in inland areas [4]; 


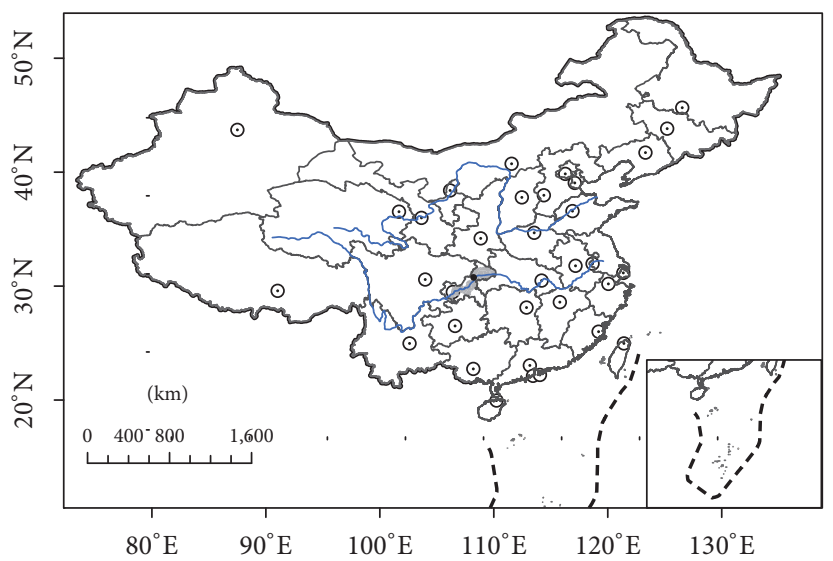

(a)

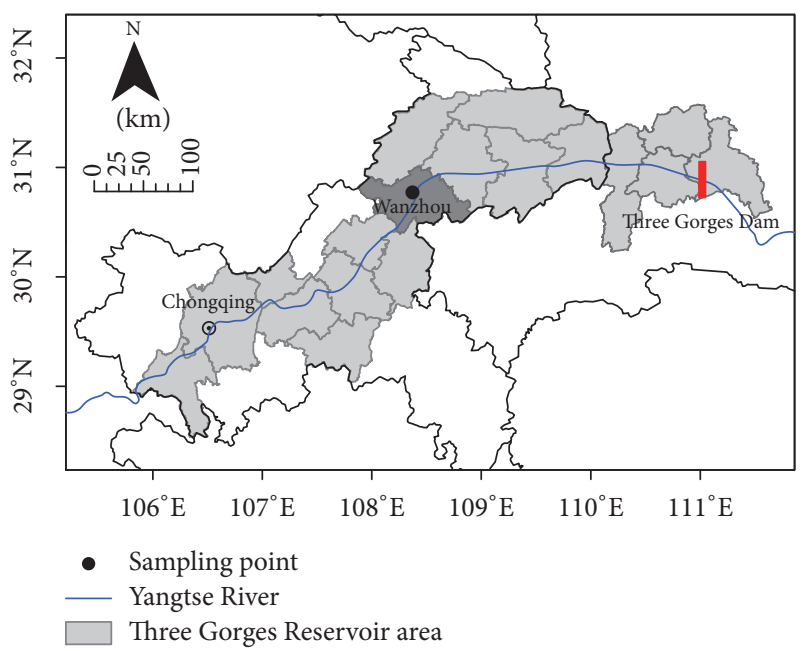

(b)

Figure 1: The sampling site in Wanzhou.

$\mathrm{SO}_{4}{ }^{2-}$ and $\mathrm{NO}_{3}{ }^{-}$are abundant in industrial or urban areas $[5,6]$.

Because large amount of coal combustion increased the $\mathrm{SO}_{2}$ concentration in the atmosphere over the past 30 years, China has become the largest acid rain region in the word [7]. Extensive acid rain was observed in the southern and southwest China in the 1990s, and it has extended to the eastern and central areas [5]. Northern China had a higher concentration of acidic ions in the precipitation than that in the south, but the $\mathrm{pH}$ of precipitation was almost higher than the threshold value of acid rain $(\mathrm{pH}=5.6)$ in Northern China, because there were enough alkaline substances (e.g., alkaline particles and $\mathrm{NH}_{3}$ ) which can neutralize the acidic components. It was estimated that the $\mathrm{pH}$ of precipitation would decrease by a factor of $1.85 \mathrm{pH}$ units in the absence of alkaline neutralization in Northern China [8]. Acid precipitation would cause huge damage to environment, including acidification of soil and water, death of animals and plants, and weathering of buildings and artifacts [9]. The sum of economic loss resulting from acid deposition in China reached RMB 176.42 billion yuan in 2000 according to the evaluation from Chinese Research Institute of Environment [10].

Chongqing has been one of the most serious acid rain polluted regions in China since the late 1970s. Simian Mountain and Jinyun Mountain in Chongqing were believed to be relatively clean in the sense of air pollution, but the average $\mathrm{pH}$ values of precipitation in the two areas were 4.3 and 4.8 in 1991-1992, respectively [11]. As the stringent national air pollution regulations were established to decrease the emission of $\mathrm{SO}_{2}$, the $\mathrm{SO}_{4}{ }^{2-}$ concentration in precipitation in Chongqing has been decreasing since 2007 [12]. However, the alleviation of the acid rain pollution was not so evident, likely due to the increase of $\mathrm{NO}_{\mathrm{x}}$ emission [13].

Wanzhou is located in the northeastern Chongqing and is the biggest city in the hinterland of the Three Gorges
Reservoir Area (TGRA), being 327 kilometers away from downtown Chongqing and 283 kilometers away from Three Gorges Dam. In the light of the important and sensitive location in the Three Gorges Reservoir, two-year precipitation samples were collected in urban Wanzhou and the major ions were analyzed. The aim of this paper is to gain better understanding of precipitation chemistry in the hinterland of TGRA and to identify its major sources.

\section{Experiments}

2.1. Descriptions of Sampling Site. Wanzhou lies at the east of Sichuan Basin with a population about one million. The urban area of the city is basically built along the two mountainous banks of Yangtze River. Wanzhou has a subtropical monsoon wet climate with four distinct seasons. The average annual temperature is $18.6^{\circ} \mathrm{C}$. In Wanzhou, there is a mild climate with an annual average precipitation amount of $\sim 1200 \mathrm{~mm}$, among which $\sim 70 \%$ are concentrated in the period between May and September. Because of the topographic condition, Wanzhou is the region with the lowest wind speed in China, and the average wind speed is $0.81 \mathrm{~m} \mathrm{~s}^{-1}$ between 2014 and 2015 (automatic weather station's data at the sampling point).

Sampling of atmospheric precipitation was performed on the rooftop of a teaching building with nine floors in Chongqing Three Gorges University (Figure 1). This sampling site is surrounded by residential areas, and three kilometers away from the downtown Wanzhou and about $600 \mathrm{~m}$ away from Yangtze River. To the west of the sampling site, there is a hill with dense vegetation and a few cultivated lands. To the east, there is a major street road (about $100 \mathrm{~m}$ away). Next to the sampling site, a weather station (Lufft WS500UMB, Germany) and atmospheric particle monitor (Thermo TEOM1405, USA) were equipped to obtain meteorological data and particle data, respectively, including wind speed and 
direction, temperature, air pressure, relative humidity, total solar radiation, and mass concentrations of $\mathrm{PM}_{2.5}$ and $\mathrm{PM}_{10}$.

2.2. Sample Collection and Analyses. The samples of precipitation were collected with a dry-wet deposition autosampler (APS-3A, Changsha Xianglan Scientific Instrument Co., Ltd.). There is a movable lid which can be stimulated by a wetness sensor to open the funnel of $300 \mathrm{~mm}$ in diameter for collection of precipitation during precipitation. Precipitation samples were collected on each rainy/snowy day between 9:00 a.m. and 9:00 a.m. the next day. After the samples were taken to the laboratory, $10 \mathrm{~mL}$ of each sample was taken to determine $\mathrm{pH}$ value (pHS-3C, Shanghai Leici Instrument Factory, China) and electrical conductivity (EC) value (sensION5, Hach, USA). Before each measurement, standard buffer and standard $\mathrm{NaCl}$ solution were used to calibrate the $\mathrm{pH}$ meter and conductivity meter. The remaining solution of samples was filtered with $0.45 \mu \mathrm{m}$ pore diameter membrane filter and then kept in $4^{\circ} \mathrm{C}$ for subsequent testing.

The anion components, including $\mathrm{F}^{-}, \mathrm{Cl}^{-}, \mathrm{NO}_{3}{ }^{-}$, and $\mathrm{SO}_{4}{ }^{2-}$, were analyzed by using ion chromatography (ICS900, Dionex Company, USA), with an IonPac AS19-HC column, $25 \mathrm{mM} \mathrm{NaOH}$ eluent, and ASRS300 suppresser. The detection limits for these anions are $0.03 \mathrm{mg} \mathrm{L}^{-1}, 0.03 \mathrm{mg} \mathrm{L}^{-1}$, $0.1 \mathrm{mg} \mathrm{L}^{-1}$, and $0.1 \mathrm{mg} \mathrm{L}^{-1}$, respectively. $\mathrm{K}^{+}, \mathrm{Na}^{+}, \mathrm{Ca}^{2+}$, and $\mathrm{Mg}^{2+}$ were analyzed by flame atomic absorption spectrophotometer. To eliminate spectral interference, cesium nitrate and lanthanum nitrate as deionizing agents were added to the potassium and sodium calibration solutions and the calcium and magnesium calibration solutions, respectively. The detection limits for $\mathrm{K}^{+}, \mathrm{Na}^{+}, \mathrm{Ca}^{2+}$, and $\mathrm{Mg}^{2+}$ were $0.013 \mathrm{mg} \mathrm{L}^{-1}, 0.008 \mathrm{mg} \mathrm{L}^{-1}, 0.02 \mathrm{mg} \mathrm{L}^{-1}$, and $0.0025 \mathrm{mg} \mathrm{L}^{-1}$, respectively. $\mathrm{NH}_{4}^{+}$were analyzed by Spectrophotometry Method of Sodium Hypochlorite-Salicylic Acid in accordance with the national standard method of China (GB 13580.11-92). In this method, $\mathrm{NH}_{4}{ }^{+}$reacted with hypochlorite and salicylic acid to produce stable blue compound, whose absorbance was determined at the wavelength of $698 \mathrm{~nm}$ by using UV-visible spectrophotometer (T6, Purkinje General Instrument Co. Ltd., China). The lowest concentration detected by this method for $\mathrm{NH}_{4}^{+}$was $0.01 \mathrm{mg} \mathrm{L}^{-1}$. The recoveries for all ions detected here were in the range of $80 \%-120 \%$ and the relative standard deviation was less than $5 \%$ for reproducibility test. A total of 207 valid samples were analyzed. After statistical analyses described in Section 2.4, the monthly data included meteorological factors, $\mathrm{PM}_{2.5}$, $\mathrm{PM}_{10}$, precipitation amount, $\mathrm{pH}$, anions, and cations, which are presented in the supplementary material (available here).

2.3. Quality Control and Assurance. In the process of ion analysis, Standard Reference Materials, produced by National Research Center for Certified Reference Materials, China, were routinely analyzed to guarantee the data quality. Six samples were removed because their data were outside the range of $(m-3 \delta, m+3 \delta)$, which was often used to exclude outliers [22], and where $m$ denotes averaged value; $\delta$ means standard deviation. The Pearson correlation between anions and cations was 0.97 ( $p<0.01$ ), suggesting credible data quality. And the data were also considered acceptable because the ratio of total cations $\left(\mathrm{H}^{+}, \mathrm{Na}^{+}, \mathrm{K}^{+}, \mathrm{Ca}^{2+}, \mathrm{Mg}^{2+}\right.$, and $\mathrm{NH}_{4}{ }^{+}$) and total anions $\left(\mathrm{F}^{-}, \mathrm{Cl}^{-}, \mathrm{NO}_{3}{ }^{-}\right.$, and $\left.\mathrm{SO}_{4}{ }^{2-}\right)$ is 1.05 , which is within the range of $1 \pm 0.25$ [23].

2.4. Statistical Analysis. The volume-weighted mean (VWM) $\mathrm{pH}$ value was calculated by

$$
\overline{\mathrm{pH}}=-\log \left[\mathrm{H}^{+}\right]=-\log \left[\frac{\sum_{j=1}^{n} 10^{-\mathrm{pH}_{j}} \cdot Q_{j}}{\sum_{j=1}^{n} Q_{j}}\right],
$$

where $\overline{\mathrm{pH}}$ is the VWM $\mathrm{pH}$ value in a month/season/year, $\mathrm{pH}_{j}$ is the $\mathrm{pH}$ value of $j$ th precipitation, and $Q_{j}(\mathrm{~mm})$ is the amount of $j$ th precipitation. The ionic concentration of precipitation was calculated by

$$
\overline{C_{i}}=\frac{\sum_{j=1}^{n} C_{i j} \cdot Q_{j}}{\sum_{j=1}^{n} Q_{j}},
$$

where $\overline{C_{i}}\left(\mu \mathrm{eq} \mathrm{L}^{-1}\right)$ is the VWM concentration of $i$ th ion in a month/season/year and $C_{i j}\left(\mu\right.$ eq $\left.\mathrm{L}^{-1}\right)$ is the concentration of $i$ th ion in $j$ th rainfall.

The non-sea salt (nss) values of any particular ion were calculated from the measured concentrations of the ions of interest using sodium ion as the reference element. This process was implemented under the assumption that all sodium is derived from marine sources [23]. The equation for the non-sea salt contribution can be written as

$$
[\mathrm{nns}-\mathrm{X}]_{i}=\left[X_{i}\right]-\left[\mathrm{Na}^{+}\right]_{i} \times\left[\frac{[X]}{\left[\mathrm{Na}^{+}\right]}\right]_{\text {sea salt }},
$$

where $[\mathrm{nns}-X]_{i}\left(\mu \mathrm{eq} \mathrm{L}{ }^{-1}\right)$ is the concentration of nss concentration of species $X$ in sample $i,\left[X_{i}\right]$ is the total measured concentration of chemical species $X$ in sample $i,\left[\mathrm{Na}^{+}\right]_{i}$ ( $\mu$ eq $\mathrm{L}^{-1}$ ) is the concentration of $\mathrm{Na}^{+}$in sample $i$, and $\left\{[X] /\left[\mathrm{Na}^{+}\right]\right\}_{\text {sea salt }}$ is the ratio of these species as measured in seawater [23].

2.5. Back Trajectories and PSCF Analysis. Cluster analysis of backward air-mass trajectories and potential source contribution function (PSCF) analysis were performed using TrajStat software on the sample date during this study period [24]. The meteorological data used for the analysis were from the Global Data Assimilation System (GDAS) of National Centers for Environmental Prediction (NCEP). The 72-hour backward trajectories of the air parcels arriving at 00:00 UTC at $1200 \mathrm{~m}$ elevation above the ground level were clustered. The PSCF values corrected by a weight factor were then calculated using the mean concentration for three anthropogenic ions $\left(\mathrm{SO}_{4}{ }^{2-}, \mathrm{NH}_{4}{ }^{+}\right.$, and $\left.\mathrm{NO}_{3}{ }^{-}\right)$[25]. The results were displayed as maps with each grid cell equal to $0.5^{\circ}$ latitude by $0.5^{\circ}$ longitude in size.

\section{Results and Discussion}

3.1. Precipitation Amount, EC, and $p H$ Distribution. The annual precipitation amounts were $1189.2 \mathrm{~mm}$ and $1081.1 \mathrm{~mm}$ 


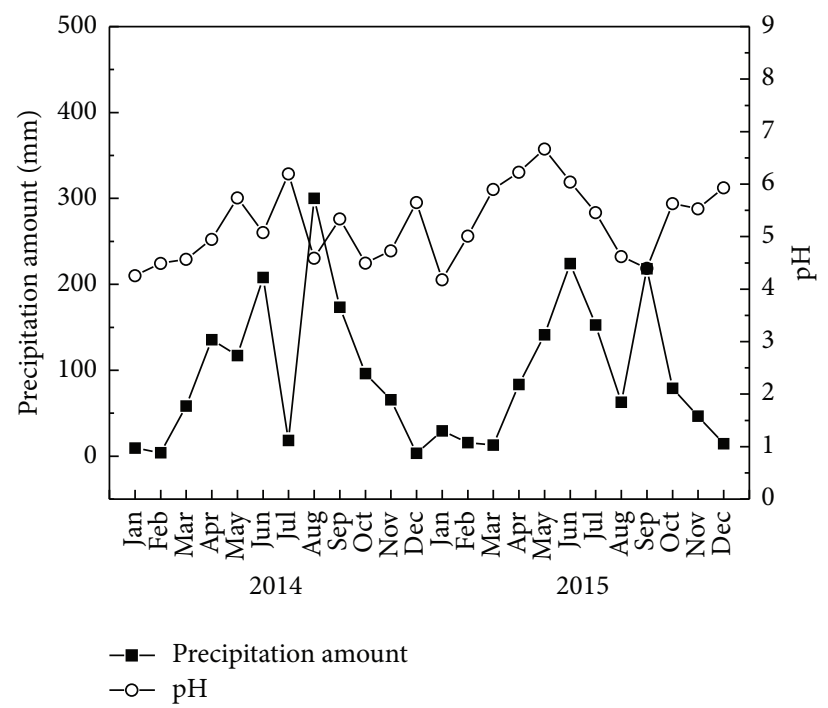

(a)

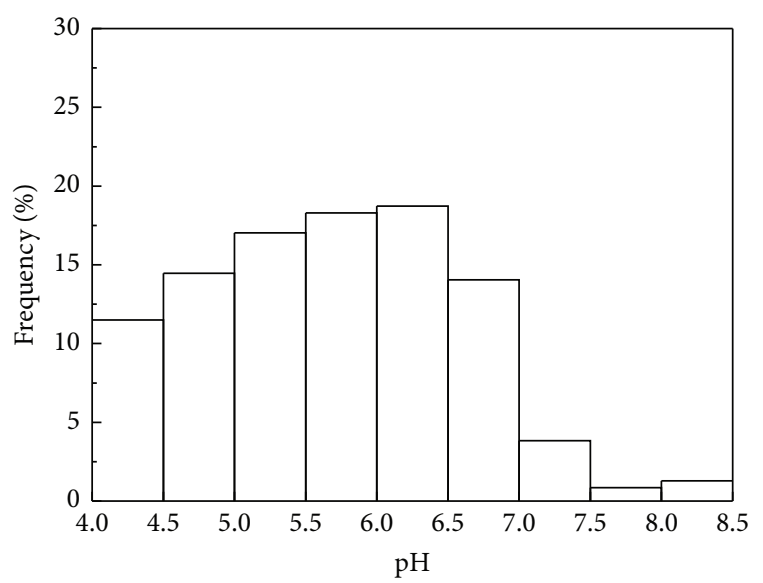

(b)

FIgURe 2: (a) Monthly precipitation amount, VWM pH, and (b) pH frequency distribution of the precipitation in Wanzhou.

in 2014 and 2015, respectively. As shown in Figure 2(a), monthly mean precipitation amount varied markedly with a peak in the summer and about $70 \%$ of the precipitation occurred during the period from May to September. These results were consistent with the long-term average precipitation levels and seasonal variations in Wanzhou [26].

The EC values of single precipitation varied in the range of $3.4 \mu \mathrm{S} \mathrm{cm}^{-1}$ to $234.0 \mu \mathrm{S} \mathrm{cm}^{-1}$ with an average of $35.9 \mu \mathrm{S} \mathrm{cm}^{-1}$, which was larger by a factor of 2.5 than that $\left(14.6 \mu \mathrm{S} \mathrm{cm}^{-1}\right)$ measured at the global atmospheric background site in $\mathrm{Mt}$. Waliguan Mountain [27]. However, this value was comparable to those measured in many other cities, such as $42.2 \mu \mathrm{S} \mathrm{cm}^{-1}$ in Shenzhen [28] and $66.5 \mu \mathrm{S} \mathrm{cm}^{-1}$ in Beijing [6], indicating that anthropogenic impacts on the atmospheric environment in Wanzhou could not be neglected.

The $\mathrm{pH}$ values of a single precipitation sample ranged from 4.0 to 8.3 with a VWM value of 5.0, lower than the $\mathrm{pH}$ of typical natural rainwater (5.6). As for the frequency of acid precipitation (Figure 2(b)), there were $46.9 \%$ of precipitation with the $\mathrm{pH}$ lower than 5.6. Additionally, 26.1\% of precipitations had $\mathrm{pH}$ lower than 5.0 , and $11.6 \%$ were strongly acidic with $\mathrm{pH}$ lower than 4.5 . It is worth noting that the arithmetic mean $\mathrm{pH}$ value of precipitation was 5.7 during the two-year study period, which was a little higher than the average (5.5) observed during the period of 2001-2009 [15]. This is an indication of the mitigation trend in acidification of precipitation in Wanzhou.

3.2. Chemical Composition of the Precipitation. Figure 3 presented the statistical results of ion concentrations and percentage share of each ion. The most abundant ions were $\mathrm{SO}_{4}{ }^{2-}, \mathrm{Ca}^{2+}, \mathrm{NH}_{4}{ }^{+}$, and $\mathrm{NO}_{3}{ }^{-}$. The average concentration of $\mathrm{NH}_{4}^{+}$together with $\mathrm{Ca}^{2+}$ reached $151.6 \mu \mathrm{eq} \mathrm{L}^{-1}$ and accounted for $68.4 \%$ of the total cations. The average concentration of $\mathrm{SO}_{4}{ }^{2-}$ plus $\mathrm{NO}_{3}{ }^{-}$was $246.51 \mu \mathrm{eq} \mathrm{L}{ }^{-1}$ which occupied $91.3 \%$ of all anions. Among the precipitation components, $\mathrm{SO}_{4}{ }^{2-}$ was the most abundant single ion, accounting for $36.3 \%$ of the total ions, followed in decreasing order by, $\mathrm{NO}_{3}{ }^{-}, \mathrm{Cl}^{-}$, and $\mathrm{F}^{-}$. For the cations, $\mathrm{NH}_{4}{ }^{+}$and $\mathrm{Ca}^{2+}$ were followed in decreasing concentration by $\mathrm{Na}^{+}, \mathrm{K}^{+}, \mathrm{H}^{+}$, and $\mathrm{Mg}^{2+}$. The total VMW concentration of the measured ions was $416.4 \mu \mathrm{eq} \mathrm{L}^{-1}$ in Wanzhou, indicating the serious air pollution in the hinterland of TGRA.

The sum of $\mathrm{SO}_{4}{ }^{2-}, \mathrm{NO}_{3}{ }^{-}$, and $\mathrm{NH}_{4}{ }^{+}$, which were the main anthropogenic ions in precipitation, accounted for $71.4 \%$ of the total ionic equivalents, while $\mathrm{H}^{+}$accounted for $3.6 \%$, demonstrating that anthropogenic sources predominated in the contributions to precipitation ions. $\mathrm{Ca}^{2+}$ and $\mathrm{Mg}^{2+}$, regarded as two kinds of main crustal-related ions, occupied together $32.5 \%$ of total ionic equivalents, indicating that crustal-derived elements had key contribution to the neutralization of the acid precipitation. $\mathrm{Nss}_{-} \mathrm{SO}_{4}{ }^{2-}$ and nss-Ca ${ }^{2+}$ accounted for $96.1 \%$ and $98.5 \%$ of the total sulfate and total calcium, respectively. Thus, the impact of sea salt on the wet deposition in Wanzhou was negligible.

The equivalent ratio of $\left(\left[\mathrm{Ca}^{2+}\right]+\left[\mathrm{NH}_{4}{ }^{+}\right]\right) /\left(\left[\mathrm{SO}_{4}{ }^{2-}\right]+\right.$ $\left.\left[\mathrm{NO}_{3}{ }^{-}\right]\right)$was further used to evaluate the degree of influence by the anthropogenic activities. The ratio of $\left(\left[\mathrm{Ca}^{2+}\right]\right.$ $\left.+\left[\mathrm{NH}_{4}{ }^{+}\right]\right) /\left(\left[\mathrm{SO}_{4}{ }^{2-}\right]+\left[\mathrm{NO}_{3}{ }^{-}\right]\right)$in the precipitation in this study reached 0.79 , which conformed with the ratio $(0.80)$ in the period between 2001 and 2009 in Wanzhou [15]. It is noted that this ratio was lower than that measured in Lin'an (0.97), Longfengshan (1.27), and Shangdianzi (0.96), three regional background atmospheric stations of World Meteorological Organization (WMO) in Yangtze River Delta, Northeast China, and North China, respectively [29]. This comparison reflected that there was more influence from anthropogenic activities on the precipitation in Wanzhou.

As compared in Table 1, the concentration levels of the ions associated with human activities $\left(\mathrm{SO}_{4}{ }^{2-}, \mathrm{NO}_{3}{ }^{-}\right.$, 
TABLE 1: VWM concentrations of major inorganic ions in the precipitation in Wanzhou and some selected areas (unit: $\mu$ eq $\mathrm{L}^{-1}$ ).

\begin{tabular}{lccccccccccccc}
\hline Areas & Periods & $\mathrm{pH}$ & $\mathrm{F}^{-}$ & $\mathrm{Cl}^{-}$ & $\mathrm{NO}_{3}{ }^{-}$ & $\mathrm{SO}_{4}{ }^{2-}$ & $\mathrm{NH}_{4}^{+}$ & $\mathrm{Ca}^{2+}$ & $\mathrm{Na}^{+}$ & $\mathrm{K}^{+}$ & $\mathrm{Mg}^{2+}$ & $\mathrm{SO}_{4}{ }^{2-} / \mathrm{NO}_{3}^{-}$ & $\mathrm{References}^{-}$ \\
\hline Wazhou & $2014-2015$ & 5.0 & 3.2 & 15.1 & 35.1 & 156.9 & 89.6 & 62.1 & 24.4 & 20.1 & 9.9 & 4.5 & This study \\
Zigui & 2009 & 4.9 & $\mathrm{ND}^{\mathrm{b}}$ & 11.8 & 63.2 & 177.2 & 90.6 & 142.6 & 11.7 & 7.5 & 18.3 & 2.8 & {$[14]$} \\
Wanzhou & $2001-2009$ & $5.5^{\mathrm{a}}$ & 8.4 & 25.3 & 43.7 & 258.3 & 126.6 & 114.4 & 27.0 & 12.7 & 29.2 & 5.9 & {$[15]$} \\
Okinawa, Japan & $2003-2005$ & 4.9 & $\mathrm{ND}^{\mathrm{b}}$ & 351 & 7.0 & 53.9 & 9.5 & 25.2 & 308 & 9.4 & 63.9 & 7.7 & {$[16]$} \\
New Jersey, USA & $2006-2007$ & 4.6 & 1.1 & 10.7 & 14.3 & 19.0 & 24.4 & 3.0 & 10.9 & 1.3 & 1.6 & 1.3 & {$[17]$} \\
Delhi, India & $2011-2013$ & 6.4 & 10.7 & 42.9 & 50.5 & 91.6 & 23.7 & 198.6 & 26.8 & 5.3 & 69.2 & 1.8 & {$[4]$} \\
Beijing & $2001-2005$ & 6.0 & 15.4 & 34.9 & 106.0 & 314.0 & 236.0 & 209.0 & 22.5 & 13.8 & 48.4 & 3.0 & {$[6]$} \\
Guijang & $2008-2009$ & 4.2 & 14.5 & 20.7 & 7.3 & 265.6 & 112.8 & 182.9 & 13.9 & 9.6 & 10.5 & 36.4 & {$[5]$} \\
Guangzhou & $2005-2006$ & 4.5 & 12.0 & 21.0 & 51.8 & 202 & 66.2 & 131.0 & 18.0 & 9.0 & 9.0 & 3.9 & {$[18]$} \\
Lijiang & $1989-2006$ & 6.1 & $\mathrm{ND}$ & 11.6 & 3.6 & 32.6 & 11.4 & 50.2 & 2.5 & $\mathrm{ND}$ & 7.7 & 9.1 & {$[19]$} \\
Shenzhen & $1986-2006$ & 5.0 & 4.5 & 37.9 & 22.1 & 74.3 & 35.2 & 77.7 & 40.3 & 7.2 & 9.7 & 3.4 & {$[20]$} \\
Chengdu & 2008 & 5.1 & 6.2 & 8.9 & 156.2 & 212.8 & 150.5 & 196.6 & 1.4 & 6.6 & 16.2 & 1.4 & {$[21]$} \\
\hline
\end{tabular}

${ }^{\mathrm{a}}$ Arithmetic mean value; ${ }^{\mathrm{b}}$ not determined.

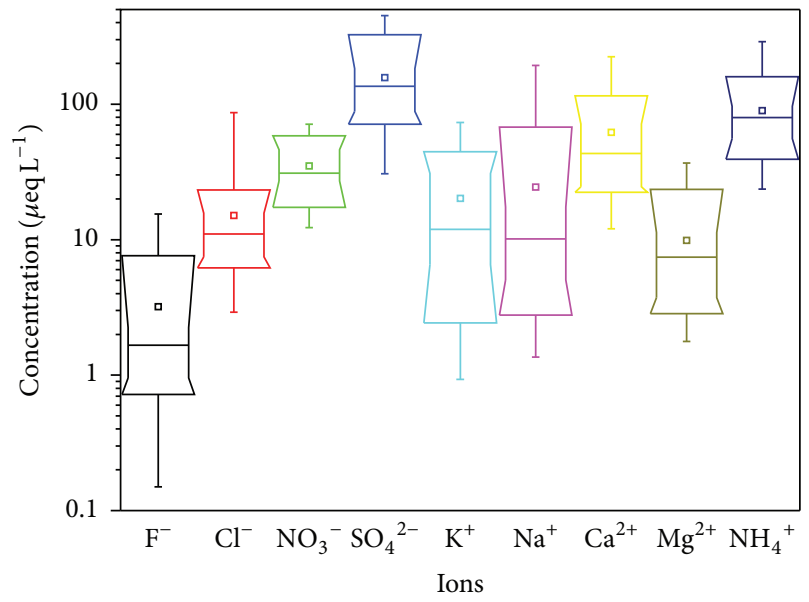

(a)

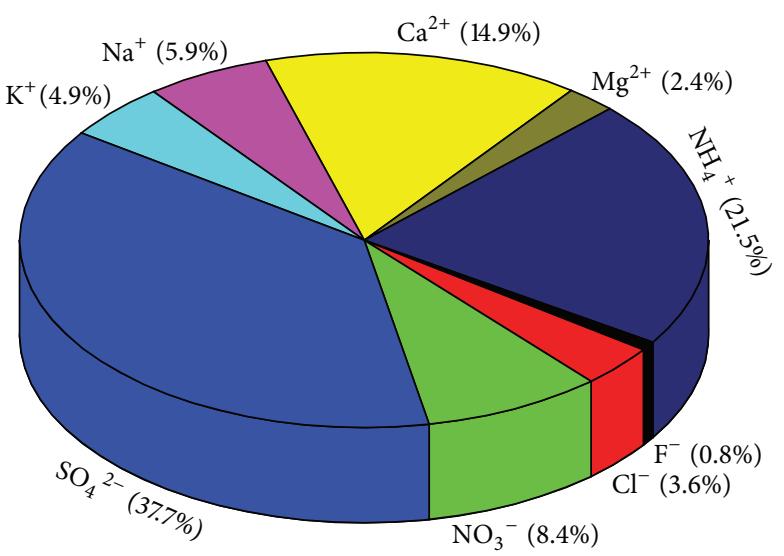

(b)

Figure 3: (a) Statistics of ions' concentration and (b) percentages of ions' VWM concentration ( $\mu$ eq $\mathrm{L}^{-1}$ ) in the precipitation in Wanzhou. The box plots indicate the minimum, 10th and 25th percentiles, median, 75th and 90th percentiles, maximum, and average (square) of each ion.

and $\mathrm{NH}_{4}^{+}$) in Wanzhou were lower than those in Beijing, Guiyang, Guangzhou, but significantly higher than those reported in Japan, India, and North America. In the case of the soil derived calcium, Wanzhou had much lower values than Beijing, Guiyang, Guangzhou, and Chengdu. In comparison with Zigui, which is located in the head region of TGRA, the concentrations of $\mathrm{SO}_{4}{ }^{2-}$ and $\mathrm{NH}_{4}{ }^{+}$were very similar in the two areas, whereas $\mathrm{NO}_{3}{ }^{-}$presented much low concentration in Wanzhou. It is noted that $\mathrm{K}^{+}$concentration was much higher in this study compared to other areas and the historical value, likely due to enhanced biomass burning in the immediate vicinity of the site.

Compared to the period from 2001 to 2009, all the ions except $\mathrm{K}^{+}$in this study exhibited decreasing trends. This was likely attributed to the implementation of industrial restructuring and emission reduction policies by local government. A typical example was that the emission amount of sulfur dioxide had been decreased from $26,400 \mathrm{t}$ in 2008 to $17,388 \mathrm{t}$ in 2015 [30], about one-third reduction within seven years.

3.3. Temporal Variations of $p H$ and Major Ionic Concentration. Figure 4 showed the seasonal variations of the EC, $\mathrm{pH}$, and precipitation amount in Wanzhou. In winter, the $\mathrm{pH}$ was 4.9 and the precipitation amount was $12.8 \mathrm{~mm}$; both were the lowest, while the EC was the highest with the value of $55.9 \mu \mathrm{S} \mathrm{cm}^{-1}$. By contrast, the lowest EC and highest precipitation amount occurred in summer and were $18.5 \mu \mathrm{S} \mathrm{cm}^{-1}$ and $161.1 \mathrm{~mm}$, respectively. This indicated that the dilution effect played an important role in determining analyte concentrations in the precipitation. The seasonal variation of $\mathrm{pH}$ was significant in the following order with a decrease trend: spring $>$ summer $>$ autumn $>$ winter. The enhanced fugitive dust, which contained many alkaline substances because of the windy weather, and local farming 

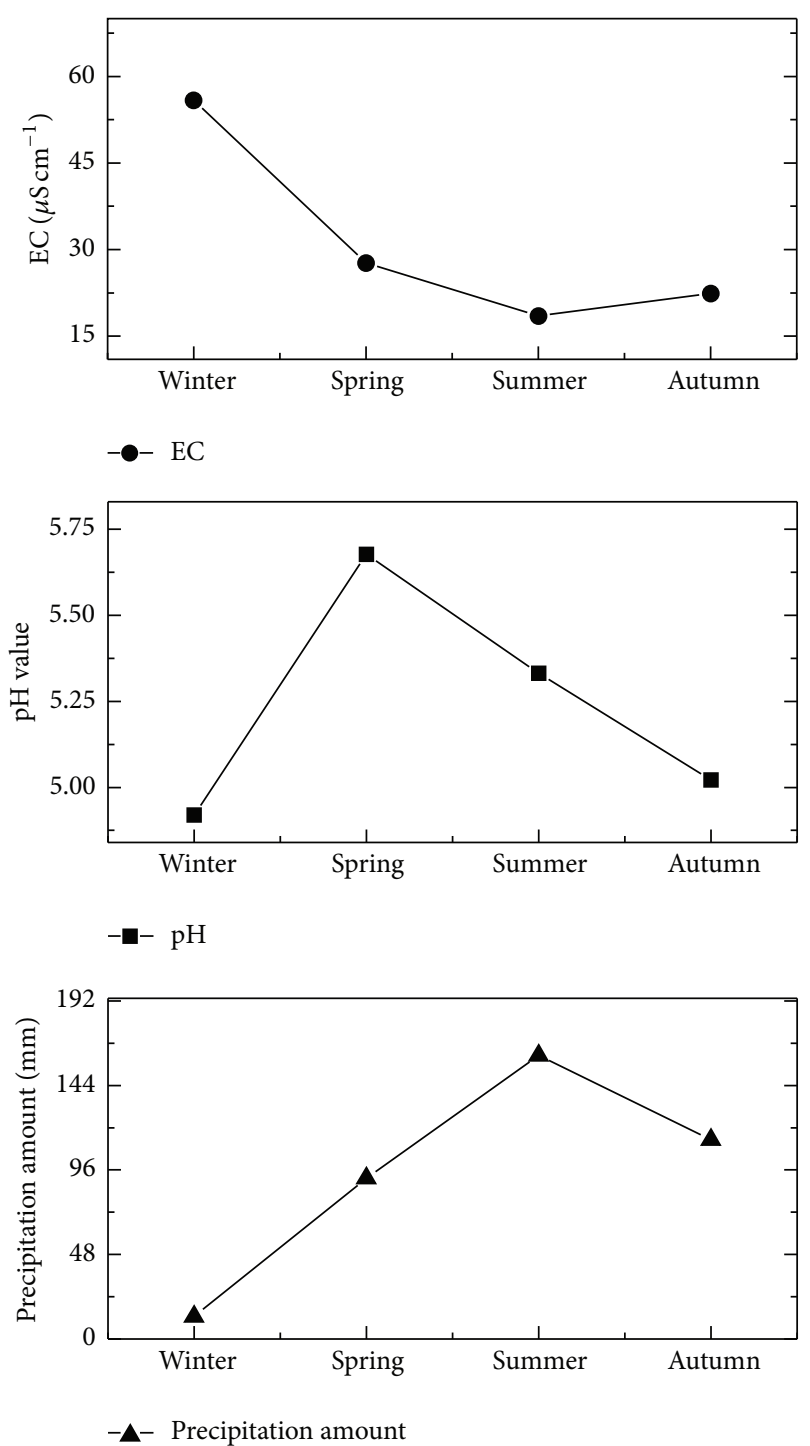

Figure 4: Seasonal variations of the two-year average EC, $\mathrm{pH}$, and precipitation amount in Wanzhou.

might be responsible for the highest precipitation $\mathrm{pH}$ in spring.

Figure 5 showed the monthly and seasonal variations in VWM concentration of ions in the precipitation in Wanzhou; both monthly and seasonal concentrations of each ion were subject to large variability. Both higher loadings of crustal-related and anthropogenic ions usually appeared during the dry months from November to April, while lower loadings appeared in rainy months. This variation of ionic concentration might be related to the seasonal distribution of air-mass origins, precipitation intensity, and emissions of pollutants. In the dry months, enhanced coal combustion caused the anthropogenic emissions of gaseous pollutants and particles. Taking $\mathrm{SO}_{4}{ }^{2-}$ as an example, the seasonal variation was completely consistent with the variation of its gaseous precursor, $\mathrm{SO}_{2}$ [31]. Additionally, atmospheric particles might play an important role in contribution of ions in precipitation, since the sum of monthly ionic concentrations was well correlated $(r=0.59, p<0.01)$ with the $\mathrm{PM}_{10}$ concentration in Wanzhou. Furthermore, the plentiful rains during rainy periods enhanced dilution effect of precipitation on ionic mass, as indicted by the negative correlations with precipitation volume (correlation coefficient $r=-0.15$ to $-0.37)$.

3.4. Acid Neutralization and the Form of Acidity. The neutralization between the acidic components and basic components determines the $\mathrm{pH}$ value of the precipitation. Balasubramanian et al. presented an equation for calculation of fractional acidity $\left(\mathrm{FA}=\left[\mathrm{H}^{+}\right] /\left(\left[\mathrm{SO}_{4}{ }^{2-}\right]+\left[\mathrm{NO}_{3}{ }^{-}\right]\right)\right.$in precipitation [32] On the other hand, neutralization factor (NF) was widely used to evaluate the acid neutralization efficiency by alkaline ions in precipitation: $\mathrm{NF}_{X i}=\left[X_{i}\right] /\left(\left[\mathrm{SO}_{4}{ }^{2-}\right]+\left[\mathrm{NO}_{3}{ }^{-}\right]\right)$, where $X_{i}$ is the chemical component of interest and all of the ion concentrations are expressed in $\mu \mathrm{eq} \mathrm{L}^{-1}[8,33]$. In Wanzhou, the $F A$ value was $7.3 \%$, which means $92.7 \%$ of the acidity had been neutralized. The NF values for $\mathrm{NH}_{4}^{+}$, $\mathrm{Ca}^{2+}, \mathrm{Na}^{+}, \mathrm{K}^{+}$, and $\mathrm{Mg}^{2+}$ during the 2-year period were 0.46 , $0.32,0.13,0.11$, and 0.05 , respectively, revealing that $\mathrm{NH}_{4}{ }^{+}$and $\mathrm{Ca}^{2+}$ were the major basic ions for the neutralization of the acidity. Nevertheless, the neutralization effect of $\mathrm{NH}_{4}{ }^{+}$and $\mathrm{Ca}^{2+}$ in precipitation in Wanzhou was much lower than that in Northern China, where the NF values accounted for 0.71 and 0.72 , respectively [8].

In this paper, the equivalent ratio of $\left[\mathrm{SO}_{4}{ }^{2-}\right] /\left[\mathrm{NO}_{3}{ }^{-}\right]$ was utilized to assess relative contributions of $\mathrm{SO}_{4}{ }^{2-}$ and $\mathrm{NO}_{3}{ }^{-}$in the acidity of precipitation. As shown in Table 1 , the $\mathrm{SO}_{4}{ }^{2-} / \mathrm{NO}_{3}{ }^{-}$ratio (4.5) in this study was much higher than those in all other Chinese cities except Guiyang, which is the capital city of Guizhou province suffering serious acid rain since late 1970s. This suggested that the precipitation acidity in Wanzhou was dominantly from excessive emission of sulfur. On the other hand, the ratio was lower than that determined during 2001-2009 in Wanzhou [15], indicating the relatively reinforced contribution of nitric acid to precipitation acidity.

3.5. Air-Mass Back Trajectories and PSCF Analysis. Figure 6(a) showed the five air-mass clustering trajectories arriving at the sampling site and Table 2 showed the VWM concentrations of $\mathrm{NH}_{4}{ }^{+}, \mathrm{SO}_{4}{ }^{2-}$, and $\mathrm{NO}_{3}{ }^{-}$of each cluster. It can be seen that all air masses converged to southern Wanzhou and finally entered Wanzhou. Cluster 1 and cluster 2, two short-distance transport trajectories, were the most important air-mass trajectories, which accounted for $39.8 \%$ and $35.7 \%$ of all the trajectories, respectively. The concentrations of $\mathrm{NH}_{4}{ }^{+}, \mathrm{SO}_{4}{ }^{2-}$, and $\mathrm{NO}_{3}{ }^{-}$in cluster 1 and cluster 2 were lower than that in cluster 3, cluster 4, and cluster 5. The trajectories in cluster 3, moving from the Yunnan Province to Wanzhou via Guizhou province, represented for $11.2 \%$ of air masses, and the precipitation in this cluster contained moderate concentrations of $\mathrm{NH}_{4}{ }^{+}$, $\mathrm{SO}_{4}{ }^{2-}$, and $\mathrm{NO}_{3}{ }^{-}$.

Precipitation in cluster 4 and cluster 5 occurred mainly in winter and spring, respectively. The trajectories accounted 
TABLE 2: VWM concentrations of $\mathrm{NH}_{4}{ }^{+}, \mathrm{SO}_{4}{ }^{2-}$, and $\mathrm{NO}_{3}{ }^{-}$in precipitation for the six trajectory clusters during 2014-2015 in Wanzhou (unit: $\left.\mu \mathrm{eq} \mathrm{L}^{-1}\right)$.

\begin{tabular}{llll}
\hline Cluster & $\mathrm{NH}_{4}^{+}$ & $\mathrm{SO}_{4}{ }^{2-}$ & $\mathrm{NO}_{3}{ }^{-}$ \\
\hline$(1) 39.8 \%$ & 85.29 & 134.19 & 24.65 \\
$(2) 35.7 \%$ & 83.37 & 118.81 & 25.98 \\
$(3) 11.2 \%$ & 92.97 & 145.66 & 29.19 \\
$(4) 9.2 \%$ & 97.62 & 206.74 & 56.51 \\
$(5) 4.1 \%$ & 90.34 & 184.53 & 40.63 \\
\hline
\end{tabular}

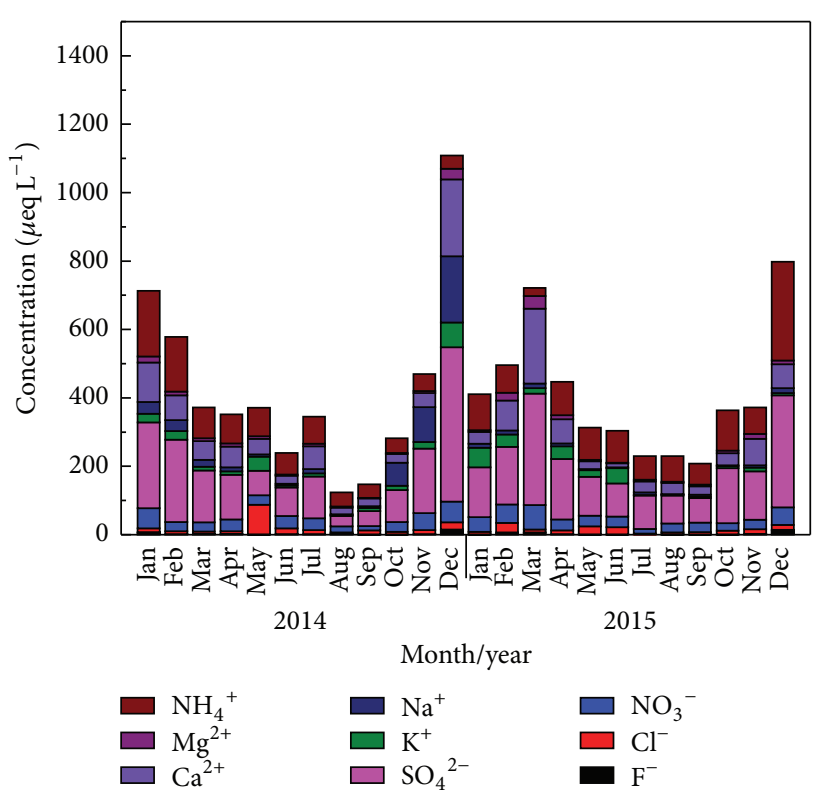

(a)

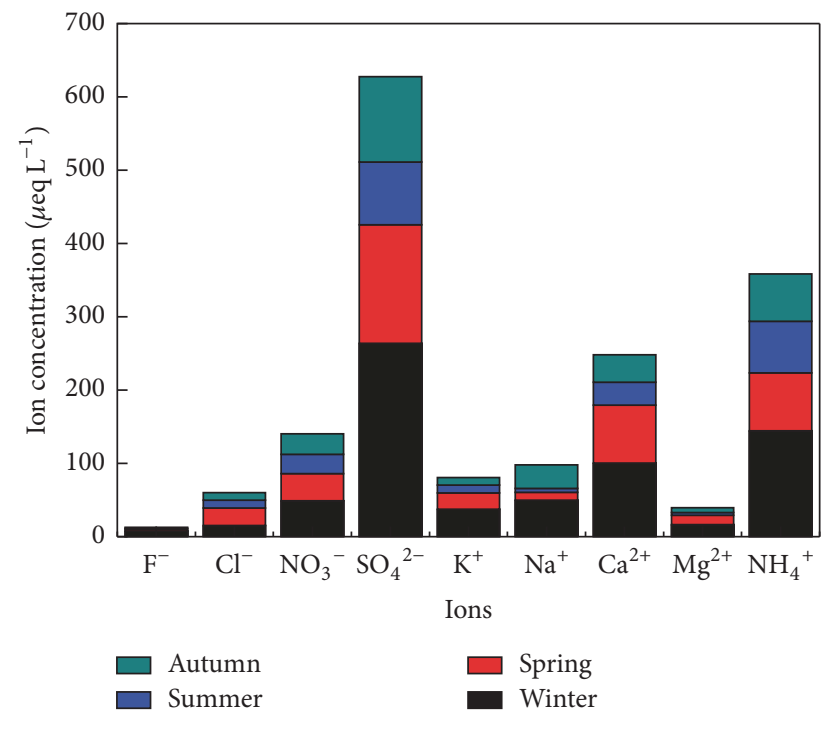

(b)

FIGURE 5: (a) Monthly variations and (b) seasonal variations in the VWM concentration of ions in the precipitation in Wanzhou.

for only $9.2 \%$ and $4.1 \%$ of the total trajectories, respectively, while the cluster-mean concentrations of $\mathrm{NH}_{4}{ }^{+}, \mathrm{SO}_{4}{ }^{2-}$, and $\mathrm{NO}_{3}{ }^{-}$were the highest in the five clusters. This could have been due to the low precipitation amount and to the traversal of the clusters through high-emission areas. For example, cluster 4 and cluster 5 passed over Chongqing city and Xian city, respectively, both of which suffered severe air pollution $[34,35]$. The potential source contribution areas of $\mathrm{SO}_{4}{ }^{2-}, \mathrm{NH}_{4}{ }^{+}$, and $\mathrm{NO}_{3}{ }^{-}$were shown in Figures $6(\mathrm{~b})-6(\mathrm{~d})$. $\mathrm{SO}_{4}{ }^{2-}, \mathrm{NH}_{4}{ }^{+}$, and $\mathrm{NO}_{3}{ }^{-}$possessed similar potential areas of source contribution. These areas were predominately concentrated on the southeast of Wanzhou, the junction region of Chongqing, Hubei province, and Hunan province. In addition, the areas in the northeast of Wanzhou had some contributions as well. Therefore, it can be concluded that the anthropogenic ions in the precipitation in Wanzhou were mostly from local sources and surrounding areas. In winter and spring, however, there was a small amount of pollutants input into Wanzhou through long distance.

3.6. Factor Analysis of Ions in Precipitation. Varimax-rotated factor analysis was utilized for the investigation of the major sources of chemical species in the precipitation (Table 3 ). Three factors were identified with the cumulative variance more than $85 \%$. And the communalities of all the ions are no less than 0.60 , indicating that these extracted factors are reasonable. There was a strong correlation between $\mathrm{Mg}^{2+}$, $\mathrm{Ca}^{2+}$, and $\mathrm{Na}^{+}$with factor 1 accounting for $34 \%$ of the total variance, pointing to the common occurrence of these ions from crustal origin. Additionally, factor 1 had a moderate relation with $\mathrm{SO}_{4}{ }^{2-}, \mathrm{NO}_{3}{ }^{-}$, and $\mathrm{F}^{-}$, implying that this factor was also likely associated with certain anthropogenic sources, such as industrial emissions, fossil fuel combustion, and fugitive dust. Factor 2 accounted for $31 \%$ of the total variance with high loadings for $\mathrm{SO}_{4}{ }^{2-}, \mathrm{NO}_{3}{ }^{-}, \mathrm{NH}_{4}{ }^{+}$, and $\mathrm{F}^{-}$, suggestive of the secondary pollution formed from their precursors in the atmosphere. The correlation coefficients were significant in statistics $(p<0.01)$ between the following ions: $\mathrm{SO}_{4}{ }^{2-}$ and $\mathrm{NH}_{4}{ }^{+}(0.68), \mathrm{SO}_{4}{ }^{2-}$ and $\mathrm{Ca}^{2+}(0.59), \mathrm{NO}_{3}{ }^{-}$ and $\mathrm{NH}_{4}{ }^{+}(0.53)$, and $\mathrm{NO}_{3}{ }^{-}$and $\mathrm{Ca}^{2+}(0.70)$. Therefore, these ions in the precipitation mainly existed as the compounds of $\mathrm{CaSO}_{4},\left(\mathrm{NH}_{4}\right)_{2} \mathrm{SO}_{4},\left(\mathrm{NH}_{4}\right) \mathrm{HSO}_{4}, \mathrm{NH}_{4} \mathrm{NO}_{3}$, and $\mathrm{Ca}\left(\mathrm{NO}_{3}\right)_{2}$. Therefore, $\mathrm{SO}_{4}{ }^{2-}$ and $\mathrm{NO}_{3}{ }^{-}$were always in neutralized forms [36]. In addition, factor 3 was indicated by high loading 


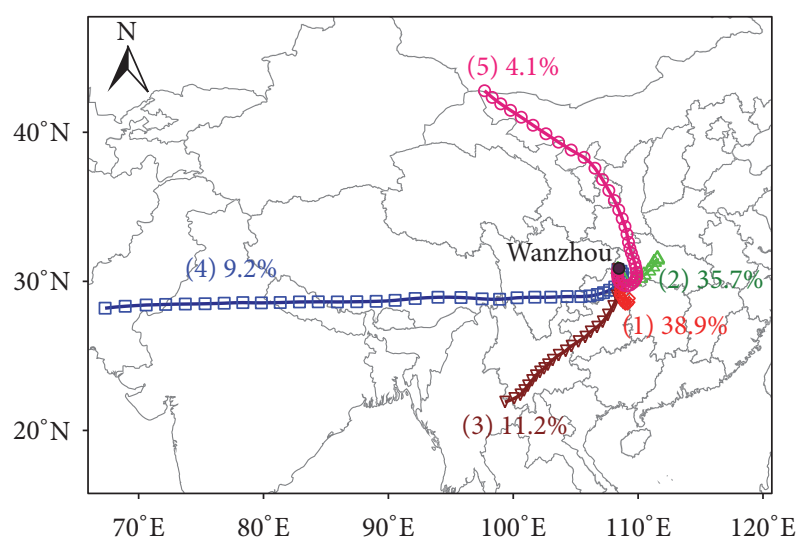

(a)

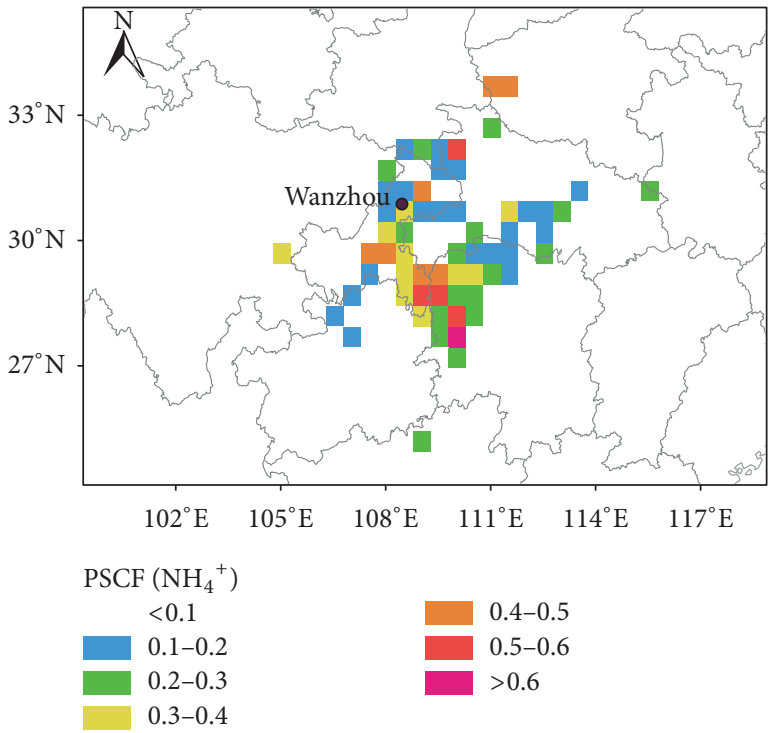

(c)

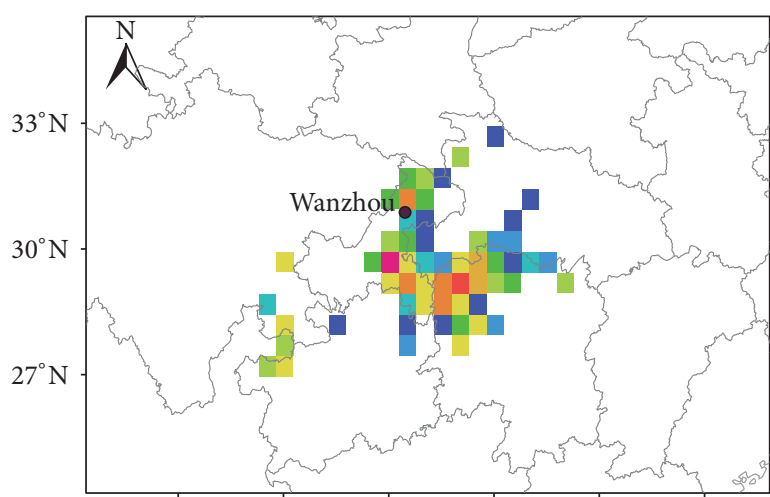

$102^{\circ} \mathrm{E} \quad 105^{\circ} \mathrm{E} \quad 108^{\circ} \mathrm{E} \quad 111^{\circ} \mathrm{E} \quad 114^{\circ} \mathrm{E} \quad 117^{\circ} \mathrm{E}$

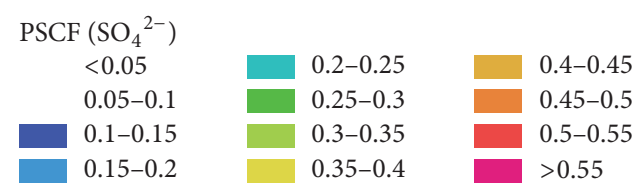

(b)
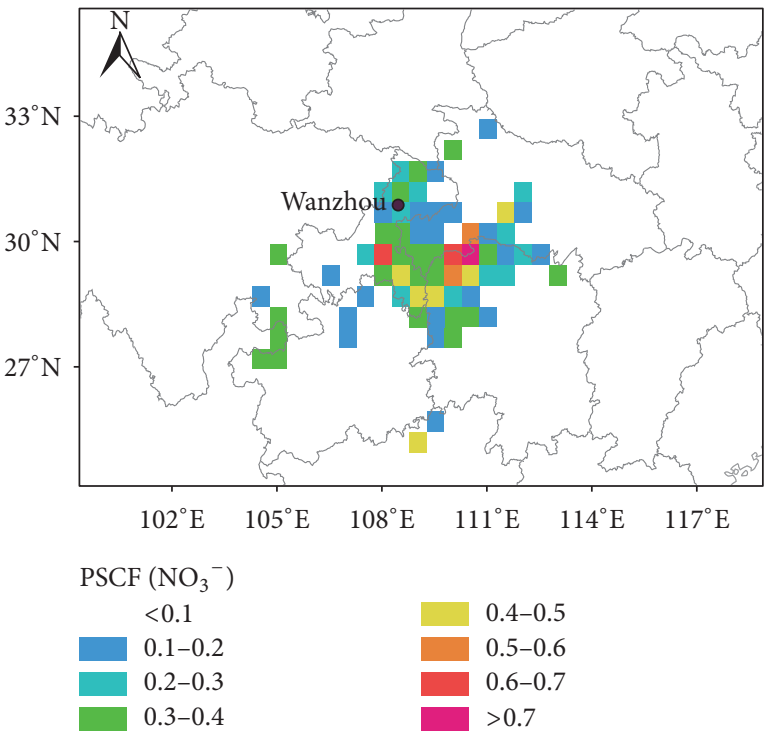

(d)

FIgURE 6: Cluster analysis (a) and potential source areas for $\mathrm{SO}_{4}{ }^{2-}$ (b), $\mathrm{NH}_{4}{ }^{+}$, (c) and $\mathrm{NO}_{3}^{-}$(d) in Wanzhou.

for $\mathrm{Cl}^{-}$and $\mathrm{K}^{+}$, implying the sources of biomass burning [37].

\section{Conclusions}

The chemical compositions of daily precipitation in Wanzhou, a typical urban area located in the hinterland of the TGRA, were investigated during the period of January 2014 to December 2015. The main findings can be summarized as follows:

(1) The $\mathrm{pH}$ of two-year precipitation samples in Wanzhou ranged from 4.0 to 8.3 with a volume-weighted mean (VWM) value of 5.0. About $46.9 \%$ of the precipitation samples had a $\mathrm{pH}$ lower than 5.6 and $26.1 \%$ samples had a $\mathrm{pH}$ lower than 5.0 , and $11.6 \%$ of precipitation was strong in acidity with the
$\mathrm{pH}$ below 4.5. EC ranged from 3.4 to $234.0 \mu \mathrm{S} \mathrm{cm}^{-1}$, with the VWM value of $35.9 \mu \mathrm{S} \mathrm{cm}^{-1}$.

(2) $\mathrm{SO}_{4}{ }^{2-}$ was the most abundant ion with the VWM concentration of $156.9 \mu \mathrm{eq} \mathrm{L} \mathrm{L}^{-1}$, accounting for $74.6 \%$ of total anions, followed in decreasing order by $\mathrm{NO}_{3}{ }^{-}, \mathrm{Cl}^{-}$, and $\mathrm{F}^{-}$. The precipitation acidity was predominantly neutralized by $\mathrm{NH}^{+}$and $\mathrm{Ca}^{2+}$, whose sum contributed $68.4 \%$ to the total cations. There were good relations between the following pairs of ions: $\mathrm{SO}_{4}{ }^{2-}$ and $\mathrm{NH}_{4}{ }^{+}, \mathrm{SO}_{4}{ }^{2-}$ and $\mathrm{Ca}^{2+}, \mathrm{NO}_{3}{ }^{-}$and $\mathrm{NH}_{4}{ }^{+}$, and $\mathrm{NO}_{3}{ }^{-}$and $\mathrm{Ca}^{2+}$, indicating their coexistence in precipitation, mostly as $\left(\mathrm{NH}_{4}\right)_{2} \mathrm{SO}_{4},\left(\mathrm{NH}_{4}\right) \mathrm{HSO}_{4}, \mathrm{CaSO}_{4}$, $\mathrm{NH}_{4} \mathrm{NO}_{3}$, and $\mathrm{Ca}\left(\mathrm{NO}_{3}\right)_{2}$.

(3) Long-distance inputs of air pollutants were less in Wanzhou. $\mathrm{NH}_{4}{ }^{+}$and $\mathrm{Ca}^{2+}$ were mainly originated from local 
TABLE 3: Varimax-rotated principal factor analysis of ions in the precipitation of Wanzhou.

\begin{tabular}{lcccc}
\hline Variable & Factor 1 & Factor 2 & Factor 3 & Communality \\
\hline $\mathrm{Cl}^{-}$ & 0.08 & 0.15 & 0.89 & 0.92 \\
$\mathrm{~K}^{+}$ & 0.15 & -0.01 & 0.29 & 0.87 \\
$\mathrm{Mg}^{2+}$ & 0.95 & 0.15 & 0.37 & 0.94 \\
$\mathrm{Na}^{+}$ & 0.54 & 0.44 & 0.07 & 0.72 \\
$\mathrm{NH}_{4}^{+}$ & -0.01 & 0.91 & 0.06 & 0.84 \\
$\mathrm{SO}_{4}{ }^{+-}$ & 0.45 & 0.81 & 0.16 & 0.86 \\
$\mathrm{NO}_{3}{ }^{-}$ & 0.59 & 0.65 & 0.13 & 0.93 \\
$\mathrm{Ca}^{2+}$ & 0.92 & 0.26 & 0.07 & 0.74 \\
$\mathrm{~F}^{-}$ & 0.47 & 0.72 & 20.5 & 85.4 \\
Variance (\%) & 33.6 & 31.3 & 64.9 & \\
Cumulative (\%) & 33.6 & &
\end{tabular}

agricultural activities and crust fraction, respectively. $\mathrm{Cl}^{-}$and $\mathrm{K}^{+}$were mainly derived from the biomass burning near the sampling site. $\mathrm{SO}_{4}{ }^{2-}$ and $\mathrm{NO}_{3}{ }^{-}$were primarily associated with local anthropogenic activities, such as coal burning and traffic emissions.

(4) The levels of ionic concentrations in precipitation in Wanzhou were similar to that in the head region of the TGRA. However, most ion concentrations were lower than that in 2000s, revealing the improvement of the air pollution in Wanzhou.

\section{Conflicts of Interest}

The authors declare no conflicts of interest.

\section{Acknowledgments}

The authors were grateful to Min Gao and Binni Shen for their assistance in sample collection and laboratory work. This study was supported by the West Action Plan of the Chinese Academy of Science (no. KZCX2-XB3-14), the National Natural Science Foundation of China (no. 31670467), Science and Technology Commission of Chongqing Projects (nos. cstc2015jcyjB0332 and cstckjcxljrc13) and Wanzhou Project (no. wzstc-042017105), Chongqing Municipality Education Commission (KJ1501006), and the open fund of CAS Key Laboratory from Reservoir Aquatic Environment.

\section{Supplementary Materials}

Table S1: monthly data of ionic concentration of precipitation, mass concentration of particulate matter, and meteorological factors in Wanzhou. (Supplementary Materials)

\section{References}

[1] M. Kajino and M. Aikawa, "A model validation study of the washout/rainout contribution of sulfate and nitrate in wet deposition compared with precipitation chemistry data in Japan," Atmospheric Environment, vol. 117, pp. 124-134, 2015.

[2] Y.-Z. Cao, S. Wang, G. Zhang, J. Luo, and S. Lu, "Chemical characteristics of wet precipitation at an urban site of Guangzhou,
South China," Atmospheric Research, vol. 94, no. 3, pp. 462-469, 2009.

[3] S. Park, B. Seo, G. Lee, S. Kahng, and Y. Jang, "Chemical composition of water soluble inorganic species in precipitation at shihwa basin, Korea," Atmosphere, vol. 6, no. 12, pp. 732-750, 2015.

[4] P. S. P. Rao, S. Tiwari, J. L. Matwale et al., "Sources of chemical species in rainwater during monsoon and non-monsoonal periods over two mega cities in India and dominant source region of secondary aerosols," Atmospheric Environment, vol. 146, pp. 90-99, 2016.

[5] H.-W. Xiao, H.-Y. Xiao, A.-M. Long, Y.-L. Wang, and C.-Q. Liu, "Chemical composition and source apportionment of rainwater at Guiyang, SW China," Journal of Atmospheric Chemistry, vol. 70, no. 3, pp. 269-281, 2013.

[6] F. Yang, J. Tan, Z. B. Shi et al., "Five-year record of atmospheric precipitation chemistry in urban Beijing, China," Atmospheric Chemistry and Physics, vol. 12, no. 4, pp. 2025-2035, 2012.

[7] W. X. Wang and P. J. Xu, "Research progress in precipitation chemistry in China," Progress in Chemistry, vol. 21, pp. 266-281, 2009 (Chinese).

[8] Y. Wang, W. Yu, Y. Pan, and D. Wu, "Acid neutralization of precipitation in Northern China," Journal of the Air \& Waste Management Association, vol. 62, no. 2, pp. 204-211, 2012.

[9] S. Eyssautier-Chuine, B. Marin, C. Thomachot-Schneider et al., "Simulation of acid rain weathering effect on natural and artificial carbonate stones," Environmental Earth Sciences, vol. 75, no. 9, article no. 748, 2016.

[10] C.-F. You and X. C. Xu, "Coal combustion and its pollution control in China," Energy, vol. 35, no. 11, pp. 4467-4472, 2010.

[11] F. Zhang, J. Zhang, H. Zhang, N. Ogura, and A. Ushikubo, "Chemical composition of precipitation in a forest area of Chongqing, Southwest China," Water, Air, \& Soil Pollution, vol. 90, no. 3-4, pp. 407-415, 1996.

[12] Y. Peng, F. Zhou, J. Cui et al., "Impact of socioeconomic and meteorological factors on reservoirs' air quality: a case in the Three Gorges Reservoir of Chongqing (TGRC), China over a 10year period," Environmental Science and Pollution Research, vol. 24, no. 19, pp. 16206-16219, 2017.

[13] L. Duan, Q. Yu, Q. Zhang et al., "Acid deposition in Asia: emissions, deposition, and ecosystem effects," Atmospheric Environment, vol. 146, pp. 55-69, 2016. 
[14] Q. Wu and G. Han, "Sulfur isotope and chemical composition of the rainwater at the three gorges reservoir," Atmospheric Research, vol. 155, pp. 130-140, 2015.

[15] Q. M. Lu, L. Zhao, L. Li et al., "Chemical composition of precipitation and its spatiotemporal variations in the Three Gorges Reservoir Region," Acta Scientiae Circumstantiae, vol. 33, pp. 1682-1689, 2013 (Chinese).

[16] H. Sakihama, M. Ishiki, and A. Tokuyama, "Chemical characteristics of precipitation in Okinawa Island, Japan," Atmospheric Environment, vol. 42, no. 10, pp. 2320-2335, 2008.

[17] F. Song and Y. Gao, "Chemical characteristics of precipitation at metropolitan Newark in the US East Coast," Atmospheric Environment, vol. 43, no. 32, pp. 4903-4913, 2009.

[18] D.-Y. Huang, Y.-G. Xu, P. Peng, H.-H. Zhang, and J.-B. Lan, "Chemical composition and seasonal variation of acid deposition in Guangzhou, South China: Comparison with precipitation in other major Chinese cities," Environmental Pollution, vol. 157, no. 1, pp. 35-41, 2009.

[19] N. Zhang, Y. He, J. Cao, K. Ho, and Z. Shen, "Long-term trends in chemical composition of precipitation at Lijiang, southeast Tibetan Plateau, southwestern China," Atmospheric Research, vol. 106, pp. 50-60, 2012.

[20] Y. Huang, Y. Wang, and L. Zhang, "Long-term trend of chemical composition of wet atmospheric precipitation during 1986-2006 at Shenzhen City, China," Atmospheric Environment, vol. 42, no. 16, pp. 3740-3750, 2008.

[21] H. Wang and G. Han, "Chemical composition of rainwater and anthropogenic influences in Chengdu, Southwest China," Atmospheric Research, vol. 99, no. 2, pp. 190-196, 2011.

[22] Y. W. Liu, X. R. Xu-Ri, Y. S. Wang, Y. P. Pan, and S. L. Piao, "Wet deposition of atmospheric inorganic nitrogen at five remote sites in the Tibetan Plateau," Atmospheric Chemistry and Physics, vol. 15, no. 20, pp. 11683-11700, 2015.

[23] W. C. Keene, A. A. P. Pszenny, J. N. Galloway, and M. E. Hartley, "Sea-salt corrections and interpretation of constituents ratios in marine precipitation," Journal of Geophysical Research: Atmospheres, vol. 91, pp. 6647-6658, 1986.

[24] Y. Q. Wang, X. Y. Zhang, and R. R. Draxler, “TrajStat: GIS-based software that uses various trajectory statistical analysis methods to identify potential sources from long-term air pollution measurement data," Environmental Modeling and Software, vol. 24, no. 8, pp. 938-939, 2009.

[25] D. Lucey, L. Hadjiiski, P. K. Hopke, J. R. Scudlark, and T. Church, "Identification of sources of pollutants in precipitation measured at the mid-Atlantic US coast using potential source contribution function (PSCF)," Atmospheric Environment, vol. 35, no. 23, pp. 3979-3986, 2001.

[26] X. Y. Zhou, S. Y. Xie, and W. Ren, "An analysis of the characteristics of precipitation in the Three Gorges Reservoir Area from 1955 to 2014 - a case study of Wanzhou in Chongqing," Journal of Southwest University, vol. 39, pp. 102-108, 2017 (Chinese).

[27] J. Tang, H. S. Xue, X. L. Yu et al., "The preliminary study on chemical characteristics of precipitation at Mt. Waliguan," Acta Scientiae Circumstantiae, vol. 20, pp. 420-425, 2000 (Chinese).

[28] Y. W. Niu, L. Y. He, and M. Hu, "Chemical characteristics of atmospheric precipitation in Shenzhen," Journal of Environmental Sciences, vol. 29, pp. 1014-1019, 2008 (Chinese).

[29] L. Yi, Y. Xiaolan, C. Hongbing, L. Weili, T. Jie, and W. Shufeng, "Chemical characteristics of precipitation at three Chinese regional background stations from 2006 to 2007," Atmospheric Research, vol. 96, no. 1, pp. 173-183, 2010.
[30] Bureau of statistics of Wanzhou district, Chongqing, Wanzhou Statistical Yearbook, 2009/2016.

[31] Y. C. Xiang, L. Y. Zhang, F. Gao, N. Zeng, and R. Z. Qian, “Analysis on relationships between sulfur dioxide concentration and dioxide concentration and meteorological factors in Wanzhou," Journal of Agricultural Catastrophology, vol. 4, pp. 45-47, 2014 (Chinese).

[32] R. Balasubramanian, T. Victor, and N. Chun, "Chemical and statistical analysis of precipitation in Singapore," Water, Air, \& Soil Pollution, vol. 130, no. 1-4, pp. 451-456, 2001.

[33] P. C. Mouli, S. V. Mohan, and S. J. Reddy, "Rainwater chemistry at a regional representative urban site: influence of terrestrial sources on ionic composition," Atmospheric Environment, vol. 39, no. 6, pp. 999-1008, 2005.

[34] H. Wang, M. Tian, Y. Chen et al., "Seasonal characteristics, formation mechanisms and source origins of $\mathrm{PM}_{2.5}$ in two megacities in Sichuan Basin, China," Atmospheric Chemistry and Physics, vol. 18, no. 2, pp. 865-881, 2018.

[35] L. Bai and Z.-L. Wang, "Anthropogenic influence on rainwater in the Xi'an City, Northwest China: Constraints from sulfur isotope and trace elements analyses," Journal of Geochemical Exploration, vol. 137, pp. 65-72, 2014.

[36] B. Kyoung Lee, S. Hee Hong, and D. Soo Lee, "Chemical composition of precipitation and wet deposition of major ions on the Korean peninsula," Atmospheric Environment, vol. 34, no. 4, pp. 563-575, 2000.

[37] H. Wang, G. Shi, M. Tian et al., "Wet deposition and sources of inorganic nitrogen in the Three Gorges Reservoir Region, China," Environmental Pollution, vol. 233, pp. 520-528, 2018. 

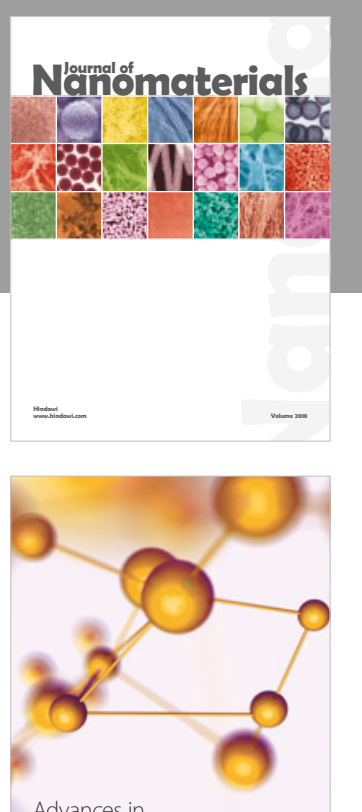

Physical Chemistry
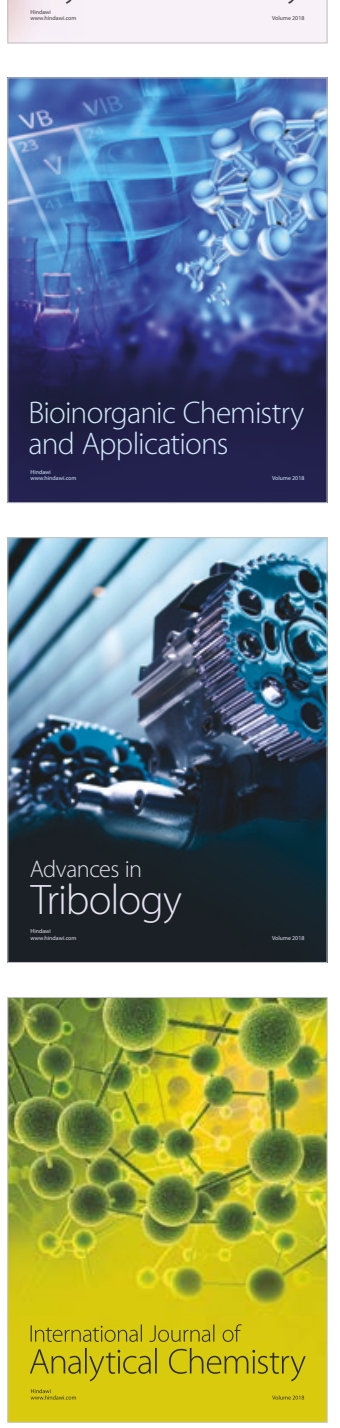

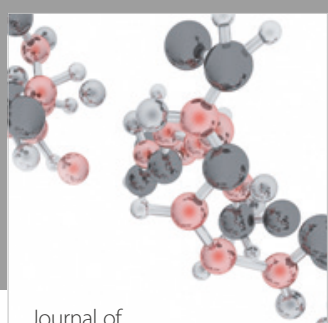

Analytical Methods

in Chemistry

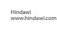

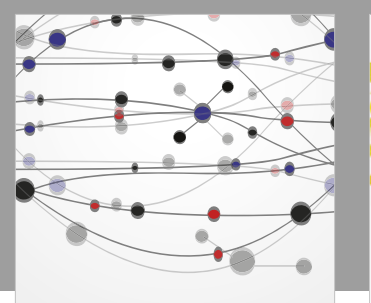

The Scientific World Journal

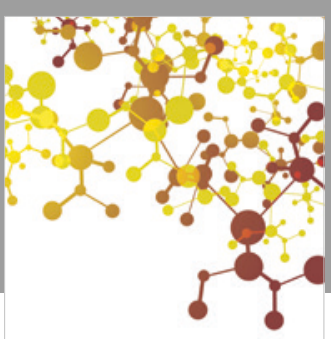

Journal of

Applied Chemistry
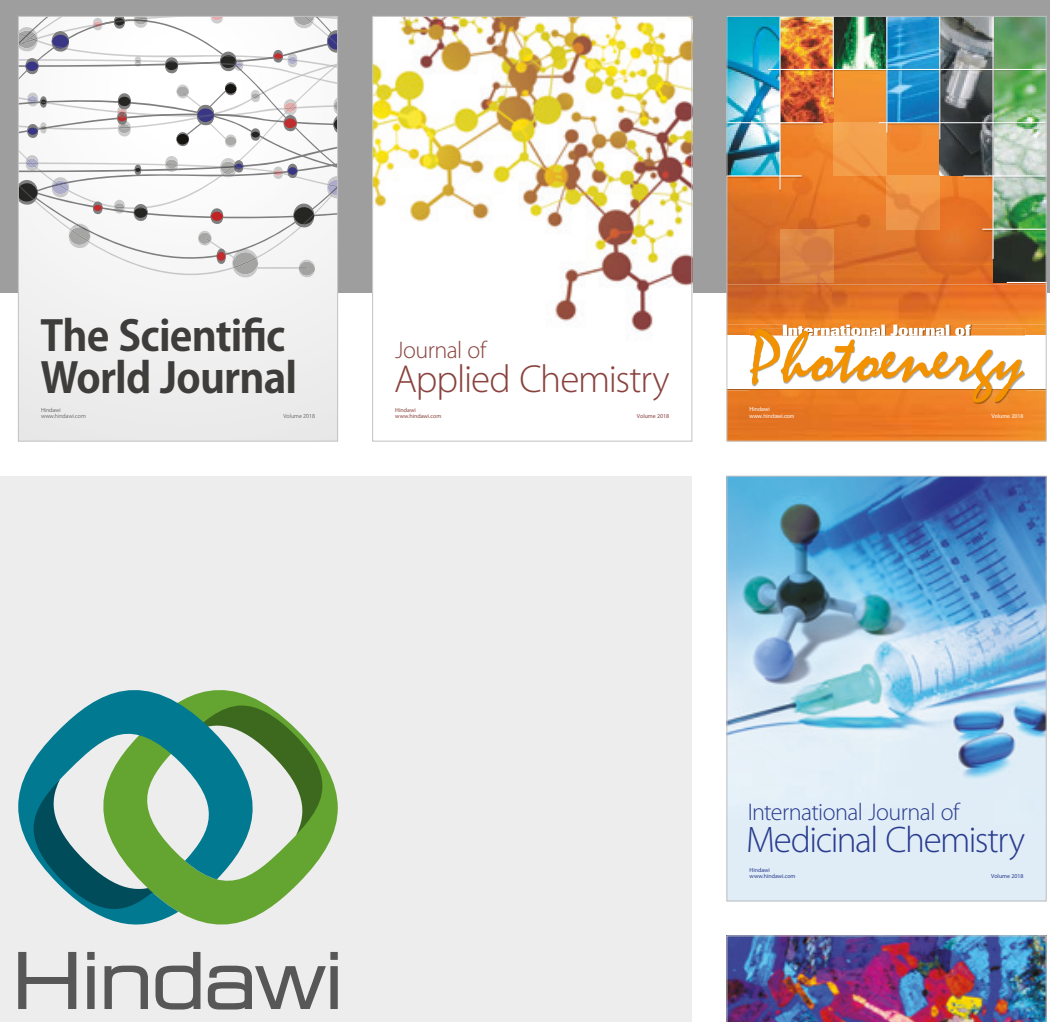

Submit your manuscripts at

www.hindawi.com
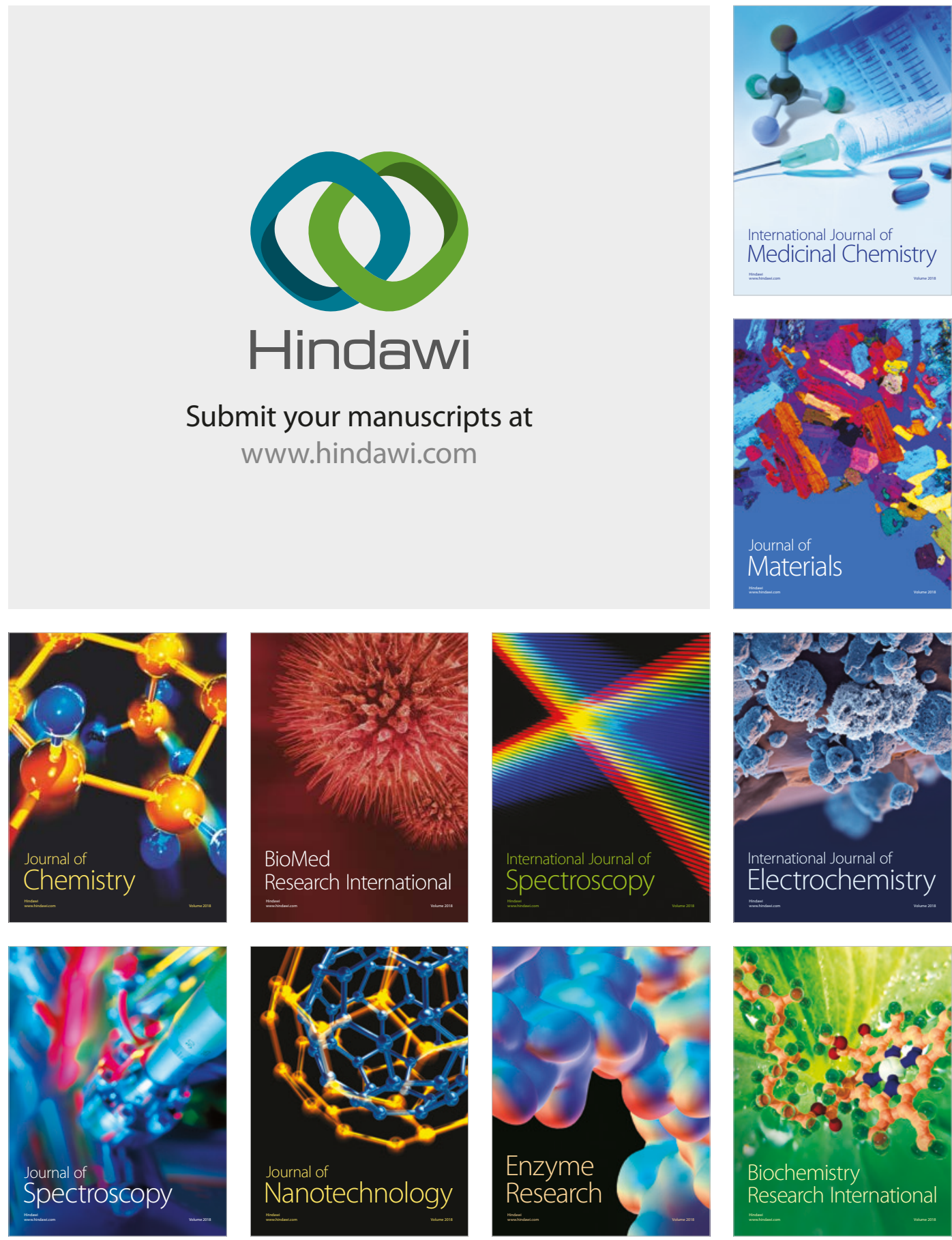
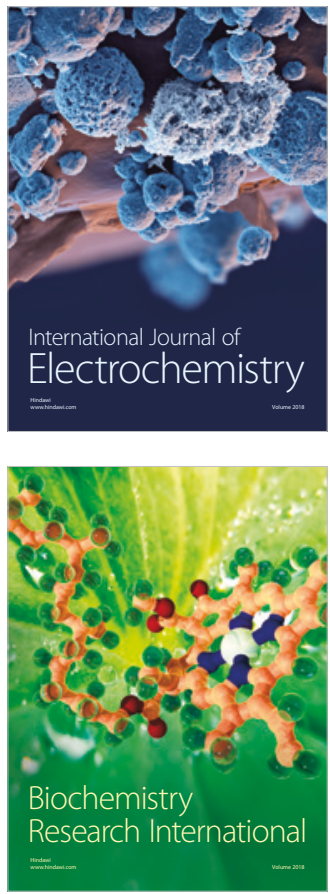